UBUNTU AND THE LAW IN SOUTH AFRICA*

ISSN 1727-3781

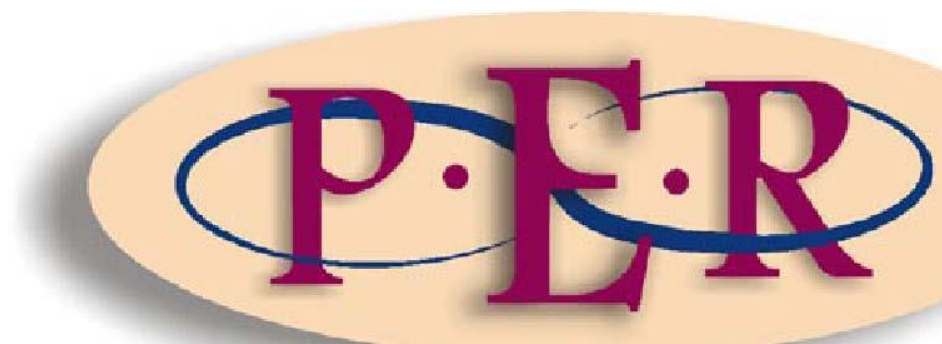

1998 VOLUME 1 No 1 


\section{UBUNTU AND THE LAW IN SOUTH AFRICA*}

Y Mokgoro*

\section{Introduction}

The new constitutional dispensation, like the idea of freedom in South Africa, is also not free of scepticism. Many a time when crime and criminal activity are rife, sceptics would lament the absence of ubuntu in society and attribute this absence to what they view as the permissiveness which is said to have been brought about by the Constitution with its entrenched Bill of Rights.

In my view, there is a patriotic obligation on all of us not to allow our Constitution and the idea of respect for human rights and dignity to slide into such disrepute.

Firstly, I would like to take this opportunity and (attempt to) demonstrate the irony that the absence of the values of ubuntu in society that people often lament about and attribute to the existence of the Constitution with its demands for respect for human rights when crime becomes rife, are the very same values that the Constitution in general and the Bill of Rights in particular aim to inculcate in our society.

Secondly, against the background of the call for an African renaissance that has now become topical globally, I would like to demonstrate the potential that traditional African values of ubuntu have for influencing the development of a new South African law and jurisprudence. I would like you to view this presentation as a contribution to the early debates on the revival of African jurisprudence as part of the total or broader process of the African renaissance.

Paper delivered at the first Colloquium Constitution and Law held at Potchefstroom on 31 October 1997. This paper was first published by the Konrad-Adenauer-Stiftung in their Seminar Report of the Colloquium (Johannesburg 1998). 


\section{The concept of ubuntu and the social values it represents}

The concept ubuntu, like many African concepts, is not easily definable. To define an African notion in a foreign language and from an abstract as opposed to a concrete approach to defy the very essence of the African world-view and can also be particularly elusive. I will therefore not in the least attempt to define the concept with precision. That would in any case be unattainable. In one's own experience, ubuntu it seems, is one of those things that you recognise when you see it. I will therefore only put forward some views which relate to the concept itself and like many who wrote on the subject, I can never claim the last word. In an attempt to define it, the concept has generally been described as a world-view of African societies and a determining factor in the formation of perceptions which influence social conduct. ${ }^{1}$

It has also been described as a philosophy of life, which in its most fundamental sense represents personhood, humanity, humaneness and morality; a metaphor that describes group solidarity where such group solidarity is central to the survival of communities with a scarcity of resources, where the fundamental belief is that motho ke motho ba batho ba bangwe/umuntu ngumuntu ngabantu which, literally translated, means a person can only be a person through others ${ }^{2}$ In other words the individual's whole existence is relative to that of the group: this is manifested in anti-individualistic conduct towards the survival of the group if the individual is to survive. It is a basically humanistic orientation towards fellow beings.

Kunene, ${ }^{3}$ however, warns against a superficial perception of the concept:

For indeed, it is not enough to refer to the meaning and profound

1 Broodryk J Ubuntu in South Africa (LLD thesis UNISA 1997).

2 Mbigi $L$ and Maree J Ubuntu: The Spirit of African Transformation Management (Sigma Press Johannesburg 1995) 1-7.

3 Kunene M "The Essence of being Human: An African Perspective\# in Inaugural Lecture 16 August 1996 Durban 10. 
concept of ubuntuism merely as a social ideology. Ubuntu is the very quality that guarantees not only a separation between men, women and the beast, but the very fluctuating gradations that determine the relative quality of that essence. It is for that reason that we prefer to call it the potential of being human.

Such potential, he states can fluctuate from the lowest to the highest level during one's lifetime, where there is constant harmony between the physicality and spirituality of life. That harmony is achieved through close and sympathetic social relations within the group - thus the notion umuntu ngumuntu ngabantu/motho ke motho ka batho ba bangwe, which also implies that during one's life-time, one is constantly challenged by others, practically, to achieve self-fulfilment through a set of collective social ideals. Because the African world-view cannot be neatly categorised and defined, any definition would only be a simplification of a more expansive, flexible and philosophically accommodative idea.

The meaning of the concept however, becomes much clearer when its social value is highlighted. Group solidarity, conformity, compassion, respect, human dignity, humanistic orientation and collective unity have, among others been defined as key social values of ubuntu. Because of the expansive nature of the concept, its social value will always depend on the approach and the purpose for which it is depended on. Thus its value has also been viewed as a basis for a morality of co-operation, compassion, communalism and concern for the interests of the collective respect for the dignity of personhood, all the time emphasising the virtues of that dignity in social relationships and practices. For purposes of an ordered society, ubuntu was a prized value, an ideal to which age-old traditional African societies found no particular difficulty in striving for. This is so because these societies had their own traditional institutions which functioned on well-suited principles and practices. Of course in view of the influence and effect that various social forces had on African societies throughout their historical development, today, the well-suitedness of those original principles and practices is often questioned and in my view correctly so. Indeed, as Ali Mazrui observes, 
... Africa can never go back completely to its pre-colonial starting point but there may be a case for re-establishing contacts with familiar landmarks of modernisation under indigenous impetus.

But then, how often have we not heard that the imposition and assimilation of even those positive contributions of western notions, institutions and culture in African societies has not been very successful? Is the explanation for that shallowness based, as Ali Mazrui further opines, on

that culture gap between the new structures and the ancient values, between alien institutions and ancestral traditions?

If there can be no reversion to the pre-colonial starting point, how then do we fill that cultural gap, where required, if we have to meet the constitutional challenges of the law that face us as South African lawyers today?

\section{Ubuntu and South African law}

Much as South Africa is a multicultural society, indigenous law has not featured in the mainstream of South African jurisprudence. Although an opportunity presented itself with the reforms effected by the Special Courts for Blacks Abolition Act 34 of 1986 and the Law of Evidence Amendment Act 4 of 1988 which among others, empowered mainstream courts to take judicial cognisance of indigenous law, not much has come of that either. Without a doubt, some aspects or values of ubuntu are universally inherent to South Africa's multi cultures. It would be anomalous if dignity, humaneness, conformity, respect, etc. foreign to any of South Africa's cultural systems. It is however, in respect of methods, approaches, emphasis, attitude etc. of those and other uncommon aspects and values of ubuntu that the concept is unique to African culture. It is thus in respect of those unique aspects that there has now arisen a need to harness them carefully, consciously, creatively, strategically and with ingenuity so that age-old African social innovations and historical cultural experiences are aligned with present day legal notions and techniques if the intention is to create a legitimate system of law for all South

$4 \quad$ Mbigi and Maree Ubuntu 5. 
Africans. Such inclusivity is important for enhancing the legitimacy of a jurisprudence which is required to manage the challenges that constitutionalism poses for us. There is therefore much room for law reform by careful prioritisation of current socio-legal problems and through appropriate research methods, find pragmatic and integrated solutions, as part of a new law management strategy.

\section{Ubuntu and the Constitution}

The Interim Constitution ${ }^{6}$ clearly set the tone for socio-political transformation in South Africa. That constitution itself created,

... a historic bridge between the past of a deeply divided society, characterised by strife, conflict, untold suffering and injustice, and a future founded on the recognition of peaceful co-existence ... for all South Africans.

In order to realise that peaceful co-existence, the Interim Constitution recognised that despite the injustices of the past, there is need for understanding, not vengeance. A need for reparation, not retaliation. In addition that constitution recognised the need for ubuntu and not victimisation.

Thus in its preamble the Interim Constitution declared:

Whereas there is a need to create a new order in which all South Africans will be entitled to a common South African Citizenship ... where there is equality between men and women and people of all races so that all citizens shall be able to enjoy and exercise their fundamental rights and freedoms, and ... it is necessary for such purposes that provision should be made for the promotion of national unity and the restructuring and continued governance of

Mbigi and Maree Ubuntu 5.

The Constitution of South Africa Act 200 of 1993.

Provision on National Unity and Reconciliation termed the postscript of the Constitution of South Africa Act 200 of 1993. 
South Africa...

The Interim Constitution therefore established a new restructured socio-political order of national unity, with a common citizenship; a new constitutional order where the Constitution reigns supreme, where all and not only some shall enjoy and exercise their fundamental rights and freedoms. However, at times when violent crime is rife, distraught members of society decry not only the loss of ubuntu, but particularly the permissiveness of constitutionalism and the idea of rights protection as is demonstrated by this expression of intense anger:

In Africa we respect the dead. That is why we believe in badimo. [However] our [new] Constitution, with all its good intent, allows people to disrespect funerals ... [And] if, as it seems, our constitution does not have any mechanism to arrest cancerous barbarism and restore moral values then it is a worthless piece of paper which is set to do more harm to us as a people than even the devil-inspired apartheid. ${ }^{8} 8$

The Interim Constitution, however did not establish a new free-for-all anarchist society where rights and freedoms are exercised freely with total disregard. The basic values of the Interim Constitution as a whole, the clearly identifiable values in the preamble and the postscript create a value system in terms of which rights and freedoms are to be claimed and exercised. Finally aware of the potential for disorder that the guarantee of rights and freedoms may have after decades of oppression and repression, these guiding values aim to set the tone for peaceful coexistence. The preamble specifically required the need for ubuntu but not victimisation. The values of ubuntu are therefore an integral part of that value system which had been established by the Interim Constitution. Where it concerns the exercise and enjoyment of individual human rights and freedoms the Interim Constitution also did not establish a system where these rights and freedoms are

8 Mogale C "We are Breeding a Generation of Scum" City Press 25 October 19973 saying further "Few things are as hurtful and embarrassing as thuggery ... at funerals, where gun-toting yahoos ... turn clause which was a rights -balancing mechanism, made specific provision for criteria to be considered when conflicting rights and interests are claimed. It was therefore also a mechanism for peaceful co-existence between individual claimants. The very cornerstone of African respect (funerals) into shame ..hile a whole nation is watching." 
exercised and claimed willy-nilly despite the claims and existence of concomitant rights of others. The limitations

The constitutional principles in the Interim Constitution, resulting from a solemn pact among negotiators at Kempton Park insisted that the new Constitution take its cue from the Interim Constitution. Not unlike the latter, the new Constitution is also the supreme law of the land and also contains an entrenched Bill of Rights, which section 7(1) describes as the "cornerstone of democracy in South Africa". The founding values of the democracy established by this new Constitution, viz. human dignity, equality, promotion of human rights and freedoms and multi-party democracy to ensure accountability, responsiveness and openness and the rule of law, arguably coincide with some key values of ubuntu(ism), e.g. human dignity itself, respect, inclusivity, compassion, concern for others, honesty and conformity. At the same time the ubuntu values of collective unity and group solidarity can translate into the spirit of national unity demanded of the new South African society. The collective unity, group solidarity and conformity tendencies of ubuntu can surely be harnessed to promote a new patriotism and personal stewardship so crucial (for a number of reasons) in the development of a young democracy. A number of similar survival issues in the law itself brought about by the challenges of constitutionalism, are easily identifiable. It is around these that law reform can harness the spirit of ubuntu(ism) to achieve appropriate responses to the demands of constitutionalism.

Whether it is for purposes of promoting the values of the Constitution by translating them into more familiar ubuntu values and tendencies, or whether it is for purposes of harnessing some unique ubuntu value, tendency, approach and/or strategy, or further whether it is for purposes of promoting and/or aligning these aspects of ubuntu with core constitutional demands ubuntu(-ism), it seems, can play an important role in the creation of responsive legal institutions for the advancement of constitutionalism and a culture of rights in South Africa.

9 S 33 Constitution of the Republic of South Africa 200 of 1993. 


\section{Ubuntu and indigenous law}

For the first time in the history of its recognition in South Africa, indigenous law and its application now has what can be viewed as constitutional status. Section 21(1) taking its cue from the Interim Constitution recognises the indigenous law institution of traditional leaders and the systems of indigenous law that they observed. Courts are specifically enjoined to apply this law where it is applicable, and do so subject to the Constitution and applicable legislation. ${ }^{10}$

The Constitution therefore seeks to bring an end to the marginal development of customary law principles. It also promotes the need to address the application of those outdated and distorted customary law institutions by requiring that they be brought in line with the values of the Constitution.

Indigenous law which is the formally recognised positive law, is replete with institutions which deserve to be discarded or re-aligned and developed. Ubuntu(ism), which is central to age-old African custom and tradition however, abounds with values and ideas which have the potential of shaping not only current indigenous law institutions, but South African jurisprudence as a whole. Examples that come to mind are:

- the original conception of law perceived not as a tool for personal defence, but as an opportunity given to all to survive under the protection of the order of the communal entity;

communalism which emphasises group solidarity and interests generally, and all rules which sustain it, as opposed to individual interests, with its likely utility in building a sense of national unity among South Africans;

- the conciliatory character of the adjudication process which aims to restore 
peace and harmony between members rather than the adversarial approach which emphasises retribution and seems repressive. The lawsuit is viewed as a quarrel between community members and not as a conflict; The importance of group solidarity requires restoration of peace between them;

- the importance of public ritual and ceremony in the communication of information within the group;

- the idea that law, experienced by an individual within the group, is bound to individual duty as opposed to individual rights or entitlement. Closely related is the notion of sacrifice for group interests and group solidarity so central to ubuntu(ism);

- the importance of sacrifice for every advantage or benefit, which has significant implicants for reciprocity and caring within the communal entity.

The shared values of ubuntu(-ism) and the Constitution and in addition, the significant and effective approaches, methods, techniques and strategies of the former are likely also to become central in shaping and formulating a new indigenous law and jurisprudence that meet the demands and challenges of constitutionalism for indigenous law. How exactly these values can be utilised to inform jurisprudential responses to the current challenges brought about by competing demands in a complex and rapidly changing South Africa, will require close examination of current shortcomings of existing institutions, their mechanisms and strategies.

Section 39(2) of the Constitution provides that in the interpretation of the Bill of Rights or any legislation, courts have a specific injunction to develop indigenous law taking into account the spirit, purport and object of the Bill of Rights. Since the values of the Constitution and at least the key values of ubuntu(-ism) do seem to converge, indigenous law may need to be aligned with these converging values. It is however, not only the system of

$10 \quad S 21(3)$. 
indigenous law which need this re-alignment. South African law as a whole is constantly placed under the scrutiny of the constitution. The values of ubuntu can therefore provide it with the necessary indigenous impetus.

\section{Conclusion}

When Chief Justice Mahomed addressed the World Jurist Association Seminar in Cape Town in February of this year, he summed up the significance of African values:

... the ageless emotional and cultural maturity of Africa is less dramatic but not less significant or potentially powerful in influencing, in shaping and in formulating the constitutional ethos which must inform and define judicial responses to jurisprudential challenges arising from competing demands in a complex and rapidly changing society. That maturity expresses itself through a collectivist [emotion] of communal caring and humanism, and of reciprocity and caring.

These African values which manifest themselves in ubuntu/botho are in consonance with the values of the Constitution generally and those of the Bill of Rights in particular. The human rights violations and indignities of the past have not served legitimacy and respect for South African law well.

The advent of constitutionalism has seen unconstitutional laws and actions invalidated and set aside. Institutions of democracy which had been created by the Interim Constitution to advance a culture of democracy and human rights have also swung into much action. Less than four years of constitutionalism has however not and could not have achieved the necessary popular understanding and appreciation for the varied implications of constitutionalism for South Africa. Nor did it and could it have restored fully the dignity of our legal system. And, in the true spirit of ubuntu/batho, no one, not the least lawyers from all walks of life can afford to sit back and watch our new-found constitutionalism slide into disrepute. Quite obviously, the complete dignification of South African law and jurisprudence would 
require considerable re-alignment of the present state of our value systems. We will thus have to be ingenious in finding and or creating law reform programmes, methods, approaches and strategies that will enhance adaptation to such unprecedented change.

The values of ubuntu, I would like to believe, if consciously harnessed can become central to a process of harmonising all existing legal values and practices with the Constitution. Ubuntu can therefore become central to a new South African jurisprudence and to the revival of sustainable African values as part of the broader process of the African renaissance.

\section{Bibliogaphy}

Broodryk J Ubuntu in South Africa (LLD thesis UNISA 1997)

Kunene M "The Essence of being Human: An African Perspective" Inaugural lecture 16 August 1996 Durban 10

Mbigi L and Maree J Ubuntu: The Spirit of African Transformation Management (Sigma Press Johannesburg 1995) 1-7

Mogale C "We are Breeding a Generation of Scum" City Press 25 October 19973

Constitution of the Republic of South Africa 200 of 1993

Constitution of the Republic of South Africa 108 of 1996

Law of Evidence Amendment Act 4 of 1988

Special Courts for Blacks Abolition Act 34 of 1986 